\title{
The Significant Social Networks of Women Who Have Resided in Shelters ${ }^{1}$
}

\author{
Scheila Krenkel ${ }^{2}$ \\ Universidade Federal de Santa \\ Catarina, Florianópolis-SC, Brazil
}

\author{
Carmen Leontina Ojeda Ocampo Moré \\ Universidade Federal de Santa \\ Catarina, Florianópolis-SC, Brazil
}

\author{
Cibele Cunha Lima da Motta \\ Universidade Federal de Santa \\ Catarina, Florianópolis-SC, Brazil
}

\begin{abstract}
The social and institutional support networks structured around women who suffer violence are strategic tools when coping with the phenomenon, which is considered a public health problem. This qualitative study was aimed at understanding the relational dynamics of significant social networks of women who have experienced family violence and have resided in a shelter. A group of 12 women participated in the study and data collection was carried out through semi-structured interviews and the social networks map. Data analysis was based on Grounded Theory and performed using the software Atlas.ti 5.0. The results revealed that the significant social networks were important sources of help and support in the process of coping with violence experienced by women. Results also showed that the persons in the social networks develop multiple functions and present an increasing level of relational commitment to women, especially after they leave the shelter.
\end{abstract}

Keywords: social networks, violence against women, family violence, coping behavior

\section{As Redes Sociais Significativas de Mulheres Acolhidas em Casa-Abrigo}

Resumo: As redes sociais e de suporte institucional, configuradas em torno da mulher que sofre violência, constituem-se em ferramentas estratégicas para o enfrentamento desse fenômeno, considerado um problema de saúde pública. Este estudo de natureza qualitativa teve por objetivo compreender a dinâmica relacional das redes sociais significativas de mulheres que sofreram violência no contexto familiar e foram acolhidas em casa-abrigo. Participaram 12 mulheres, sendo os dados coletados por meio da entrevista semiestruturada e do Mapa de Redes. A organização e análise dos dados foi com base na Grounded Theory, com o auxílio do software Atlas.ti 5.0. Os resultados evidenciaram que as redes sociais significativas se mostraram importantes fontes de ajuda e apoio ao longo do processo de enfrentamento da violência vivenciado pelas mulheres. Observou-se o desempenho de múltiplas funções das pessoas das redes e o aumento do grau de compromisso relacional com as mulheres, sobretudo após a saída da casa-abrigo.

Palavras-chave: redes sociais, violência contra mulher, violência na família, enfrentamento

\section{Las Redes Sociales Significativas de Mujeres Encaminadas Para Casa de Acogida}

\begin{abstract}
Resumen: Las redes sociales e institucionales se constituyen en herramientas estratégicas para el enfrentamiento de la violencia, considerado, en la contemporaneidad, un problema de salud pública. El objetivo del estudio fue comprender la dinámica relacional de las redes sociales significativas de las mujeres víctimas de violencia familiar que fueron encaminadas para casa de acogida. Participaron 12 mujeres, siendo utilizadas entrevistas semiestructuradas y el mapa de redes. La organización y análisis de los datos se basa en la teoría fundamentada y se utilizó los recursos del software Atlas.ti 5.0. Los resultados mostraron que las redes sociales significativas fueron: (a) importantes fuentes de ayuda y apoyo a lo largo del proceso de enfrentamiento de la violencia vivido por las mujeres, (b) las personas de la rede desempeñaron múltiples funciones e, (c) aumento del grado de compromiso relacional de las personas con las mujeres, principalmente, después de la salida de la casa de acogida.
\end{abstract}

Palabras clave: redes sociales, violencia contra la mujer, violencia domestica, enfrentamiento

Violence is considered as a complex and multifaceted phenomenon that emerges and takes form in individuals' relational dimension and is sustained in the light of the sociocultural contexts. Therefore, it is important to consider the peculiarities involved in the phenomenon, such as the

\footnotetext{
1 Paper deriving from the primary author's master's thesis, under the advice of the second author and co-advice of the third, defended in 2014 in the Graduate Program in Psychology at Universidade Federal de Santa Catarina. Support: National Council for Scientific and Technological Development - CNPq (Protocol No. 132265/2013-3).

${ }^{2}$ Correspondence address:

Scheila Krenkel. Universidade Federal de Santa Catarina, Campus Universitário Reitor João David Ferreira Lima, Centro de Filosofia e Ciências Humanas, bloco c, Trindade. CEP 88040-500. Florianópolis-SC, Brazil. E-mail: scheilakrenkel@gmail.com
}

persons' psychological development, the affective and social relational network they construct and the sociocultural values of the context the violence is inserted in.

Violence is characterized by the actions performed under threat, using physical strength or power, individual or institutionally, resulting in harm to someone's vital development, mutilation or death (Organização Mundial da Saúde [OMS], 2002). Violence against women can be defined as any gender-based action or omission that causes death, injury, physical, sexual or psychological suffering, moral or property damage, which may happen in the domestic sphere or elsewhere, among relatives or in any intimate affective relationship (Secretaria de Políticas para as Mulheres, 2011). 
Epidemiological data show that the violence problem is equivalent to chronic and degenerative diseases. Around the world, one out of every five days of absence from work among women is due to violence and between 40 and $70 \%$ of homicides against women are committed by intimate partners (OMS, 2002). In Brazil, in a study by Waiselfisz (2012), it is shown that, between 1980 and 2010, approximately 92 thousand women were murdered by their partners. These incidents mainly happened at home.

Violence causes harm to the women's vital development. Examples of this harm include increased anxiety, depression, social isolation, fear, low self-esteem, constant employment changes and reproductive health problems can be mentioned (Poll Cabrera, Alonso Poll, \& Mederos Ávilla, 2012; Santos \& Moré, 2011). In view of the severity and complexity of the violence problem the women experience, over the years, measures and actions have been taken for protection and coping with violence. Among the advances, the creation of public policies can be mentioned, in which the consolidated forwarding of women under threat or at risk of death to shelters is highlighted. These are institutionalized spaces that are considered as an important protective device in the social support network and a potential resource to cope with the violence situations (Secretaria de Políticas para as Mulheres, 2011).

Women's search for help in the protective networks constituted to cope with the violence, as well as the acceptance to be sheltered at these institutions, can be motivated by the experience of the extreme situations the violence generates. In that sense, among the strategies used, both the search for precincts and referral centers for women's care can be mentioned, as well as the search for help from people in their social networks. As regards the search for the social networks, in the context of violence against women, studies show that relatives are often the first persons called upon in search of help (Lettiere \& Nakano, 2011; Santi, Nakano, \& Lettiere, 2010). Besides the search for relatives, other studies indicate the search for friends, neighbors and colleagues, besides psychologists, social workers and religious representatives (Estrada Pineda, Olaizola Herrero, \& Rodríguez Díaz, 2012; Santos \& Moré, 2011). The influence of the social networks, whether institutional or personal, around people in a certain situation, makes the support received create feelings of belonging to a group, strengthen self-esteem, give meaning to life, improve adaptation skills and the quality of relationships (Christakis \& Fowler, 2009; Estrada Pineda et al., 2012; Sluzki, 1997).

According to Sluzki (1997), the social networks comprise significant relations, distinguished from other relations and which can offer help and support at times of crisis; they are one of the key pieces for individual wellbeing, as they influence healthcare and adaptation to difficult situations. The term significant social networks refers to the sum of the people the individual perceives and names as significant and important, based on his/her experience and the quality of the mutual bond constructed, which perform functions in a singular manner that help to cope, in this case, with the violence situation. The main form of significant networks are the family, friends, colleagues from work or school and the community, including health and assistance services, neighbors and people from the same religious belief, who provide help and support, which can reduce the effects of a crisis situation.

An individual's social networks can be analyzed based on the structural characteristics, the functions the people perform and the attributes of the bonds established among their members (Moré \& Crepaldi, 2012; Sluzki, 1997). The structural characteristics are the network properties analyzed as a whole, described based on Size (number of people), Density (connection among network members), Composition (distribution of network members), Dispersion (accessibility), and Homogeneity or heterogeneity (demographic and sociocultural characteristics).

The network functions are considered as the predominant type or the combination of the exchange established between the individual and the people in the network, which can be: Social company (joint activities or being together), Emotional support (empathy, stimulus and support), Cognitive guide and counsel (sharing information, counseling), Social regulation (reassertion of roles and responsibilities), Maternal or service help (financial/material help, indication of specialists/health services) and Access to new contacts (connection between people and networks). Each bond established with the people in the networks possesses attributes, which are the specific properties of each relationship, characterized by: Predominant function(s), Multidimensionality (how many functions a person performs), Reciprocity (retribution to the other of the same function received), Intensity (level of intimacy), Frequency of contacts (preservation of contact to maintain intensity) and History of the relationship (since when the people know one another and what experience actives the bond) (Sluzki, 1997).

Concerning the aspects indicated so far, it should be mentioned that the reaction of the people women turn to in search of help can influence their action or isolation in view of the violence problem, as the comments the significant social network provides can contribute, or not, to drive them towards self-care, making decisions to cope with the crisis situations, besides permitting their social and psychological empowerment. In view of the networks' impact on the individual development, the meanings attributed to these networks, to the functions they perform and to the existing level of relational commitment should be considered, as the networks can both help and impede the promotion of change. In that sense, the way the network members relate and organize their bonds, the level of intensity and relational commitment they establish mutually constitute the quality of the relations and the relational dynamics of the significant social networks (Andolfi, 2003; Sluzki, 1997). 
In that framework and in view of the lack of studies on the influence of the social networks in the context of family violence against women in Brazil, the objective in this study was to understand the relational dynamics of the significant social networks of women who were victims of violence in the family sphere and who were welcomed at shelters. The aim in this research was to contribute to the understanding and/or deepening of knowledge on the network dynamics, mainly through the functions their members perform, showing their importance in the context of violence studies and in the search to improve intervention strategies used by professionals who work with this demand.

\section{Method}

\section{Participants}

In this qualitative study, the participants were 12 female victims of family violence who were welcomed at a shelter in the South of Brazil, affiliated with the Social Service Secretary in the city where the data were collected. The shelter possesses seven rooms and can receive 28 people per day, with seven places for women and the remainder for their children. The place offers a multidisciplinary team of 15 psychology, education and social service professionals who, through their work, grant conditions for the development of personal and social autonomy and the strengthening of self-esteem. The women remain at the shelter until they are in appropriate emotional and safety conditions to return to social life, which is discussed together with the professionals.

The following criteria were adopted to include the participants in this study: (a) being over 18 years of age; (b) having experienced family violence; (c) having resided at the shelter in 2012 and 2013; (d) having spent at least 10 days at the shelter; (e) living in the city where the shelter was located. The participants were between 21 and 68 years old, with a mean age of 32 years. Five women had not finished primary education, eight worked and 11 had children. Five participants were married (four of them with the perpetrator of the violence); the mean family income was R $\$ 1,310.00$. Concerning the type of violence they were victims of physical, psychological, sexual and financial violence were mentioned, among which the participants recognized and emphasized psychological violence. In all cases, the intimate affective partner committed the violence. The length of the affective relationship ranged between 1.3 and 14.6 years. The participants spent between 12 and 117 days at the shelter.

\section{Instruments}

Semistructured Interview. The items that guided the semistructured interview referred to: (a) the participants' experience at the shelter, (b) coping strategies the participants used before and after leaving the shelter, (c) people from significant social networks who helped to cope with the violence situation, so as to investigate: who these people were, the facts that occurred and functions they performed in that situation and the proximity in terms of the bond that existed between the people in the network and the participants. It should be highlighted that the semistructured interview also supported the construction of the Network Map.

Network Map (Sluzki, 1997). In line with the phases proposed by Moré and Crepaldi (2012). Through this instrument, the interview items can be further explored, registering the level of intimacy and quality of the individual's relationship with the people in his/her significant social network, at one moment or in one specific situation. The Network Map consists of three circles and four quadrants. The internal circle represents the intimate or daily relations, the intermediate circle refers to the relations with a lesser degree of intimacy, with personal/social contact, and the external circle corresponds to the occasional relations or with acquaintances. The four quadrants of the Network Map are represented by the family, friendships, community relations (including neighbors, people from the same church and health and assistance services) and work or study relations (Sluzki, 1997). In view of the relation of the research participants with the people (women/users and professionals) at the Shelter where they were, a subdivision was included in the structure of the Network Map, in the Community quadrant, adding the item Shelter, as shown in Figure 1:

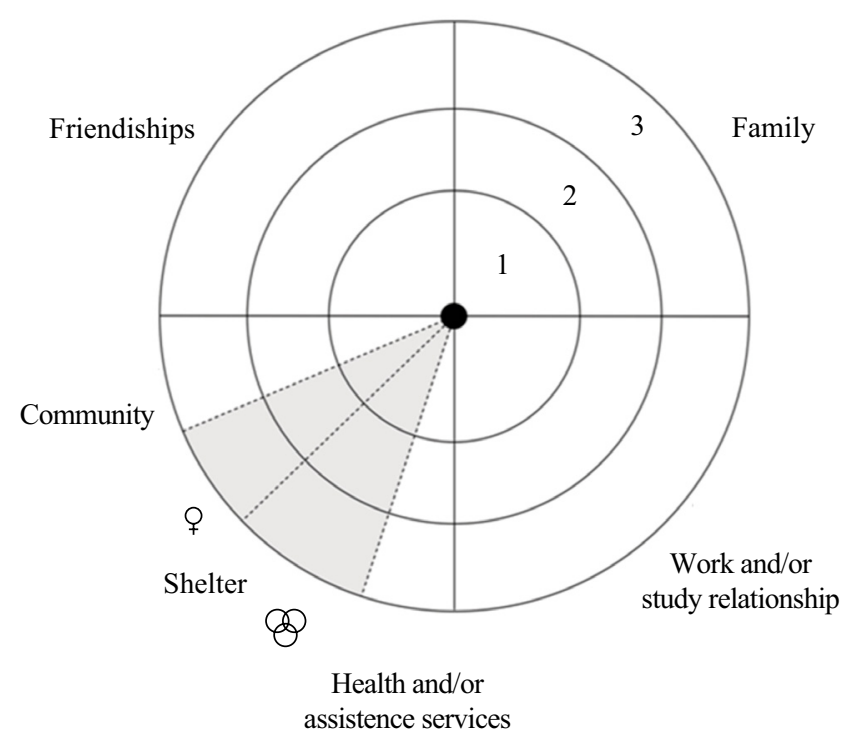

Relationship types according to degree of significance:

1. Intimate, daily relationships

2. Personal relationships with contact

3. Occasional relationships

Symbols

† Sheltered women

$\$$ Professionals from shelter

Figure 1. Network Map Model from A rede social na prática sistêmica: Alternativas terapêuticas, by C. E. Sluzki (C. Berliner, Trans.), 1997, São Paulo, SP: Casa do Psicólogo. Copyright [1996] by Carlos E. Sluzki. Adapted by adding the item Shelter with permission. 


\section{Procedure}

Data collection. To collect the data, first, the names of the women who complied with the inclusion criteria were surveyed, totaling 64. To respect the ethical aspects of the research and preserve the information secrecy of the women who resided at the shelter, initially, the professionals (social assistants and psychologists) of the Social Service Secretary who attended to the women while they stayed at the shelter contacted them by phone. Next, the telephone was passed to the main researcher, who introduced herself, explained the research objective and invited the woman to participate. Only 14 women could be contacted, all of whom accepted to participate in the study at first, but two of them did not attend on the day scheduled, resulting in 12 participants. The collection was scheduled at the Social Service Secretary, according to the participants' availability. The semistructured interview was held before the construction of the Network Map and during the same meeting. The entire process was audio-recorded and transcribed.

Data analysis. The data organization and analysis process was based on the Grounded Theory (Strauss \& Corbin, 2008) and the qualitative analysis software Atlas. ti 5.0 was used, through which the data from different instruments can be compared, systemized and categorized (Muhr, 2004). The construction of the main categories was based on successive readings, so that a set of analysis elements could be identified that supported the comparison of similar and different aspects among all data. This process led to the construction of the categories and their respective subcategories of analysis, which supported the understanding of the central phenomenon studied. The categories that emerged were: (a) family relations, (b) friendship relations, (c) community relations, (d) work and/or study relations, (e) absence of significant social networks. The names of the categories were based on the names of the quadrants of the Network Map, the research instrument used, following the proposal of Moré and Crepaldi (2012).

\section{Ethical Considerations}

This study received approval from the Institutional Review Board of the Universidade Federal de Santa Catarina (Protocol No. 251.240 / CAAE: 12882513.3.0000.0121) and complied with the ethical premises of National Health Council resolution 466/2012. With a view to information secrecy, each participant was identified using the letter $\mathrm{P}$, followed by the number indicating the order of the interview (P1, P2, P3 and so forth until P12).

\section{Results and Discussion}

To better contextualize the results and discussion of the data in this study, it should be mentioned that, before staying at the shelter, the participants were victims of death threats and homicide attempts by the person who committed the violence, living in conditions of social isolation and control of their social activities by their partner. In that sense, the results joined elements about the people in these women's significant social networks, in terms of their organization and structure, in view of the level of relationships and the functions of the people who helped the women to cope with the violence, in the period before the complaints and during and after their stay at the shelter.

\section{Family Relations}

This category presents elements related to the people from the family network, who offered help to the women through the performance of different functions. As regards the relatives the participants had contact with, the mother, father, siblings and children stood out who, among the functions Sluzki (1997) highlighted, mainly offered emotion support by listening to and receiving the women. In that context, help from physically distant relatives and the strengthening of the relationship with the children were also observed, especially after leaving the shelter. The extended family, in general terms, mainly referred to the aunts and uncles who were present in the first two circles of the Network Map and were mentioned as a source of emotional support because they "always had a word of comfort" (P4). Concerning these relatives' predominant functions, advice and material help were observed, as they donated furniture for the women's new house and money to help with the children's expenses. Among the relatives who offered material help, the sisters and brothers-in-law stand out, mainly in terms of the needs that emerged after the departure from the shelter, when these people were ready to welcome the women at their homes and/or helped them to seek and build a new home. What the search for relatives as a problem coping strategy is concerned, these study findings are in line with the research by Santos and Moré (2011), which show that the successful strategies the women used include the search for family members to talk about the violence situation.

The functions of social company and social regulation were not mentioned frequently in this study, referring to spending time talking and combined with the advice offered to the women, respectively. The limited frequency of these functions is understandable when considering that the violence phenomenon definitely affects the relations of proximity, in this case with the extended family. The possibility of social regulation, in turn, in the sense of the dialogues established between the women in situations of violence and their relatives, caused some kind of problematization, which helped them to construct strategies to cope with the situation experienced.

Based on the elaboration of the General Network Map (Figure 2), which joins the information regarding all people on the individual Maps of the 12 participants, during the period before the women's stay at the shelter, the family network was small and weakened, with five participants who did not mention any relative who was important to cope 
with the violence during that period. In line with these data, the studies by Dutra, Prates, Nakamura and Villela (2013) and Santos and Moré (2011) reveal that the absence of relatives may be related to fear, guilt and/or shame because of the violence situation, making the women take distance from the family relations and remain socially isolated. On the other hand, this study shows that, when the women left the shelter, the number of relatives increased, with greater concentration of people in the internal circle, showing the increased degree of relationships and the family members' more effective participation.

Concerning the number of people present in each participant's networks, very numerous networks may become ineffective, as the people may suppose that somebody is already taking care of the problem. Very small networks, on the other hand, can overburden the people. Therefore, an average (eight people) network size is ideal to effectively act on the problem (Christakis \& Fowler, 2009; Sluzki, 1997). As regards the aspects related to the dispersion, based on the analysis of the participants' Network Maps, a greater concentration of people could be verified in the internal circle of the "family" quadrant, showing a greater degree of proximity between the women and their relatives. In that sense, Sluzki (1997) appoints that having closer people favors and speeds up the answers to the search for help in view of a crisis situation, as the access to these people is easier.

Concerning the access to the people in the intermediary and external circles of the Network Map, the participants mentioned that this happened by telephone, through which they received emotional support and advice from relatives who were distant. Therefore, the family stood out in terms of size and dispersion, as a network with different functions and a stronger relationship with the women. Hence, in terms of professional intervention, the data resulting from

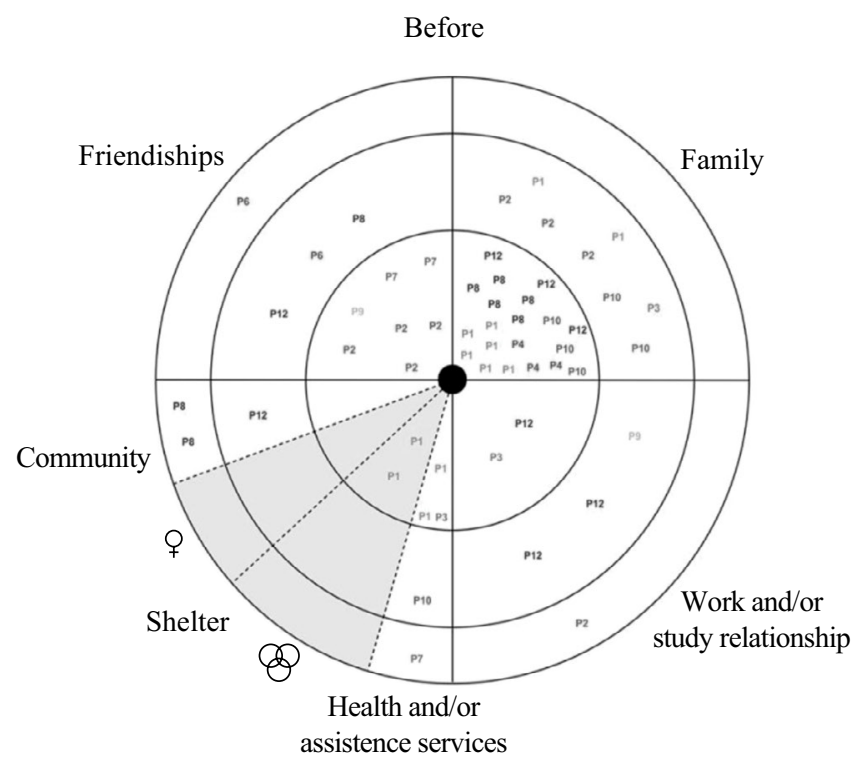

the analysis of a social network's dispersion characteristics should be further elaborated, so as to be able to detect the effect of the degree of proximity established between the women in violence situations and the people in their network. This shows both the people who receive them and those people who contribute to the maintenance of the problem the women experience.

\section{Relationships of Friendship}

This category described the elements in the functions of the participants' friendship network. The help mainly came from friends, who performed multiple functions, particularly emotional support, advice and material help and services. The emotional support was understood based on moments of listening, combined with advice to leave the relationship and denounce the person who committed the violence.

During the people's stay at the shelter, friends were indicated as important because of the company and support they offered to the women during the visits that happened at the social service secretary. When the women left the shelter, the network of friendship, like that of the relatives, stood out by offering housing and financial help until the participants were able to reestablish themselves: "When I left the shelter, she [friend] got me a stove, she got me a mattress, she got me everything. I needed food, she got it for me. I needed someone to take care of the children, she was there" (P6). The narratives revealed that the frequency of the participants' contact with the network of friendship seems to have favored the dialogue and decision making in search of professional help to get out of the violence situation. As sources of emotional support, friends were empathetic and expressed concern with the situation the participants were going through. Thus, the women could trust them to talk about their problem. They were also mentioned as good

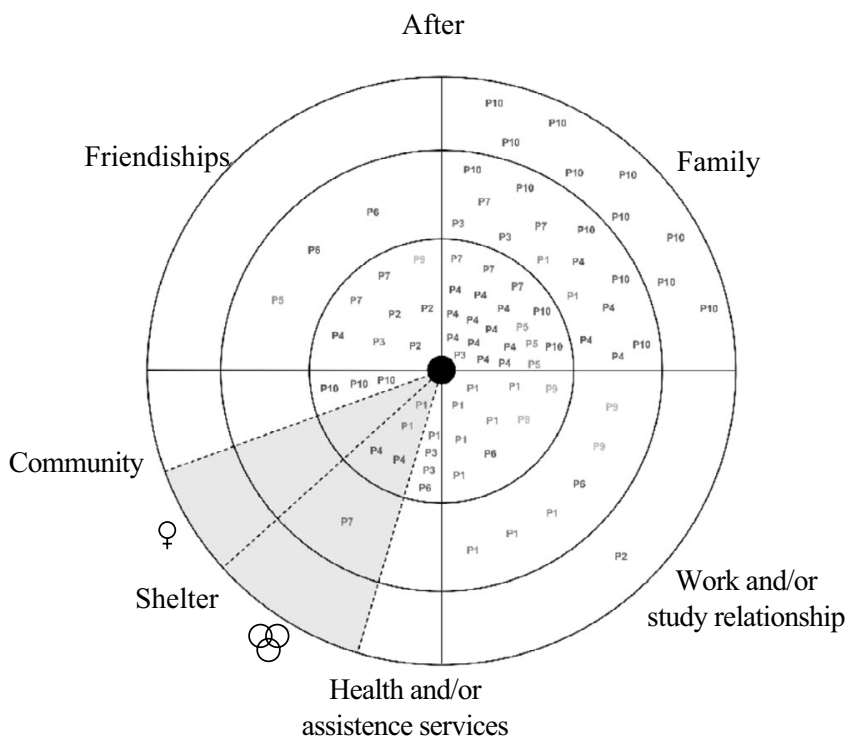

Figure 2. Network Maps for the periods "Before" and "After" the stay at the shelter. 
company because of the moments of relaxation, which made the participants momentarily forget what they were going through without having to talk about their problem. Hence, the company, listening, support and advice were present in the relation with friends. In line with these data, studies (Estrada Pineda et al., 2012; Lettiere \& Nakano, 2011; Santi et al., 2010) show that, in the entire extra-family network, the network that is most used to cope with the violence is the friendship network, mainly in terms of emotional support and social company.

Although the friendship network can be considered small in this study, its multiple functions could be observed, receiving and helping the women in situations of violence. The network of friendships mainly consists of women and the homogeneous characteristics in the relation with the participants may have favored the proximity and the performance of multiple functions in view of the situation of family violence. Concerning the networks' movement during the periods before and after the departure from the shelter, the number of friends decreased. On the other hand, a less disperse network was observed with stronger relationships among the people, that is, the friends became closer to the women, making the access to these people easier, with faster help responses when a new crisis situation happened.

\section{Community Relations}

This category joined elements of the help the participants received from neighbors, people from the same church, health and/or assistance services and people from the shelter. Initially, the participation of neighbors and members of the same church is highlighted, such as catechists, priest, ministers and missionaries, who were part of the Network Map in five out of 12 cases. The people from the same church offered emotional support and advice, which helped the participants to reflect on the situation they were going through, besides financial help and food and clothing donations when they left the shelter. The role of the neighborhood in helping the women facing violence was limited. The participants only mentioned two neighbors, besides repeated and failed requests for help: "I've already asked the neighbor for help, I've cried for help, but they don't interfere. I don't know if it's out of fear, but they don't interfere" (P7). This participant's statement shows that the neighbors' distancing may be related to the fact that they prefer not to interfere in the couple's relation, expecting them to solve their problems alone, as well as to the fear of retaliations these women's partner may commit. In the community quadrant, there is a subdivision related to the people linked to the health and/or assistance services, which was represented by the physicians and one nurse. These professionals gave advice and forwarded the people to other network services for the protection of women in situations of violence.

The head nurse talked to me, informed me that there's this shelter, I didn't know it existed [...] She called here to the social service secretary, made an appointment $[\ldots]$ Then I was attended by the social worker and the psychologist and at the same time I decided to go to the shelter. (P7)

With regard to the access to new contacts and the consequent forwarding to other services, studies have shown that, when attending to women in situations of violence, in general, the health professionals' role is to treat what is related to their practice, that is, the visible signs of the violence (Dutra \& Villela, 2012; Lettiere \& Nakano, 2011). In the statement above, the nurse offered more than apparent (cuts and injuries) care, leading to the forwarding to the city's social service secretary, in a sensitive and welcoming manner, which is why she was part of the participant's network map. This level of meaning this professional received calls for reflection on the need to sensitize the professional practices in violence situations, which can be one way to redefine the professional perspective beyond what is visible and beyond the interpretations of violence against women, surpassing stereotypes and myths regarding the theme. Thus, the health professionals may overcome the fragmentation inherited from the biomedical model and start to consider the complexity of the phenomenon in their practice, providing holistic care in accordance with the principle of the Unified Health System (SUS).

In the same category, police officers, the social workers, deputy and prosecutor are highlighted, appointed as people who advised the participants concerning their situation and forwarded them to services where they could find help. In line with Dutra and Villela (2012) and WHO (2002), it is important for the professionals who work with the violence demand to have continuing education, based on the women's listening and welcoming, on their acknowledgement as people with rights and on the forwarding articulated with the other sectors of the protection network for women, mainly when the situation is life-threatening. In this quadrant of the Map, people from the shelter where the women were welcomed were also mentioned. The other women sheltered were mentioned as important to exchange experiences, offer emotional support and because of the reciprocal support among them, but the bonds were not maintained after leaving the shelter. This information is in line with the study by Ramos and Oltramari (2010), which indicates that the possibility to share feelings and histories with other women at the shelter, who went through similar situations, permitted reflections on the violence problem. Concerning the relation with the professionals at the shelter, the emotional support function took the form of listening and care for the women and their children, acting as mediators of contact and relationships in this process.

\section{Work and/or Study Relationships}

This category joined elements of the relationship established with the people in the participants' work and/or study network, who were important in the process of coping 
with the violence before and after leaving the shelter. In the study relations, teachers, colleagues and the school principal were highlighted, present on two participants' Maps. Teachers were mentioned because they offered emotional support at times of listening and because they were available for occasional help, while the colleagues also served as cognitive guides and counselors. In the work relations, the colleagues, supervisor, responsible, head, driver and psychologist were mentioned, present on five participants' Network Map. Filing the complaint regarding the violence situation was encouraged by the head, psychologist and person in charge, who offered the women advice, emotional help through listening and financial help by a wage or holiday advance, so that these women could recover after leaving the shelter. This finding is in accordance with Santos and Moré (2011), in which bosses were people who advised the women to denounce their partner and helped them financially to allow them to reestablish themselves after the separation. This aspect illustrates the importance of the work relations and the people's sensitivity to the women's condition, as they could help them to gain emotional and financial recognition.

It should be mentioned that six participants did not include any person from the work and/or study relationship on their Maps, stating that they did not feel comfortable to talk about their personal life in these environments. One of them, who worked at different places as a general maintenance worker, said she omitted her marital status to prevent people from asking any questions.

I did not make any comments, I never talked about my life regarding what I was going through at home, I never opened up to anyone, you see? Until today, at work, I just say that I am separated and, depending on where I work, I say that I am married, because of the situation. (P10)

According to the narratives, aspects that prevented the women from talking about their situation include: shame and fear of people judging them. Hence, these factors end up contributing to the women's social isolation, making them take distance from the people in their network and hampering the request for and/or receipt of help in this kind of situation (Dutra et al., 2013).

\section{Absence of Social Networks}

The analysis of the above categories revealed indicators of the women's distancing process from their significant social networks, mentioned in the different quadrants of the Network Map the participants built. In that sense, this category joined elements specifically related to the absence of contact with the significant social networks throughout the violence process. Among the reasons that resulted in the participants' isolation from their relational network, the family's discredit of the violence situation stands out, based on three main reasons: (a) because the person who committed the violence shows to be a good and calm person in front of the relatives, (b) because the women did not tell other people details of what happened in the relationship out of "fear or shame", and (c) because some relatives mentioned that fights between intimate partners were "normal" and that these should be solved between them. In that sense, Dutra et al. (2013) appoint that the women's distancing from the people their partner considers unwanted, the death threats and retaliations, and the shame of remaining in a violent relation are aspects of the women's social isolation. In line with this information, other participants in this study report that they did not talk about their violence situation to friends and relatives because the partners did not allow them to have contact with other people, which caused distancing from the family and friendship network.

When I went to the shelter, I had taken distance from all of my friends, I could not talk to anyone [...] My family called, I didn't answer because he wouldn't let me [...] I even disconnected the phone so that nobody would call me because he used to fight with me if someone called me. (P5)

This report illustrated the power relation between the participant and her partner was observed, in which the form of domination limited the woman's contact with her networks, contributing to the slow search for help to find a way out of the violence cycle. In that sense, social isolation is a potential risk factor that, associated with the conditions of social vulnerability and the lack of significant social networks in terms of support compromises individual development and strengthens feelings like shame and guilt, while an effective social network plays a positive role with regard to self-esteem and the ability to cope with crisis situations (Christakis \& Fowler, 2009; Leonidas, Crepaldi, \& Santos, 2013; Orlandi, 2011; Sluzki, 1997). Hence, to help and understand the relational dynamics established between the women in situations of violence and their significant social network, it is important to consider the variables Sluzki (1997) appoints, based on contemporary changes, in which: (a) more people live alone, (b) society's lower requirements to participate in social activities like church, clubs or volunteer organizations, and therefore lower social pressure in terms of the standards that are to be followed, (c) people have less children living far from home, (d) the families or couples change homes or cities more diligently in the course of life, (e) the number of activities involving the extensive family is limited.

Specifically in the violence context, the distancing from the family or extra-family networks is characteristic, remaining emotional and geographical distant, whether out of fear, shame or guilt, based on a closed system with strict borders. This aspect leads to reduced social regulation, as these frontiers cannot be surpassed (Moré, 2014; Sluzki, 1997), which can contribute to sustain the woman's condition 
of vulnerability and dependence on the partner. Hence, the absence of networks is considered as a factor that hampers the escape from the violence situation, contributing to the continuation of the problem and increasingly feeding the violent cycle in a recursive manner.

Based on the extreme situation of violence the women experience, this study attempted to reveal the role of the significant social networks in the context of violence against women, in terms of their structure, organization and functions. In that perspective, the networks and their functions were an important strategy to cope with the violence situation the participants in this study experienced. In methodological terms, the potential of the Network Map should be highlighted as an instrument to describe and visualize the social networks at a certain time in a person's life. Through this instrument, the main objective of this study was further elaborated, through the integration of the data present in each quadrant, considering the level of relationships, the intensity levels of the bonds and the functions the people in the participants' networks performed in view of the violence situation. In that sense, the significant social networks' importance in the violence context was acknowledged, as the people the women in this study mentioned were capable of effectively offering help, through the intensity of their mutual relationships, through the performance of their functions and through the welcoming of the women's emotional and material needs. In this study, the presence of social isolation and a small and scattered network was also verified, especially before the women went to the shelter, which may have contributed to their longer stay in the violent relationship.

In professional terms, based on the understanding of the relational dynamics of the significant social networks, they can be used as an effective resource to receive the women, with a view to the possibility of attentive listening, mainly considering the networks' function, in view of the sociocultural context in which the demands of violence emerge. Therefore, searching and/or granting visibility to instruments that contribute to the women's better protection makes the work/welcoming of the psychologists and the multidisciplinary teams more effective. The Network Map can also add up to the range of protection strategies in the search for allies in the co-accountability process of care for these women, favoring a possible way out of the violence situation. Concerning the study limitations, the sociocultural context the research was developed in should be noted, which is the South of Brazil. The context is considered as a "producer of meanings" that permeate the participants' narratives and exercised a determinant effect in the decisions made in view of the violence situation. Also, results were presented on a specific moment in the participants' life, considering the search for help to cope with the violence. Hence, research should focus on different time periods, so as to verify the movements in the networks of women who resided at a shelter, aiming to identify whether they are at risk and/ or exposed to violence again. In addition, studies on the possibilities and limits of the professionals' practices are needed, considering the significant social networks as part of the set of intervention strategies.

\section{References}

Andolfi, M. (2003). Manual de psicología relacional: La dimensión familiar. Bogotá, Colombia: Corporación Andolfi González.

Christakis, N. A., \& Fowler, J. H. (2009). Connected: The surprising power of our social networks and how they shape our lives. New York, NY: Little, Brown.

Dutra, M. L., Prates, P. L., Nakamura, E., \& Villela, W. V. (2013). A configuração da rede social de mulheres em situação de violência doméstica. Ciência \& Saúde Coletiva, 18(5), 1293-1304. doi:10.1590/S1413-81232013000500014

Dutra, M. L., \& Villela, W. V. (2012). O setor saúde e a configuração da rede social de mulheres em situação de violência doméstica. BIS, Boletim do Instituto de Saúde, 14(3), 266-273.

Estrada Pineda, C., Herrero Olaizola, J., \& Rodríguez Díaz, F. J. (2012). La red de apoyo en mujeres víctimas de violencia contra la pareja en el estado de Jalisco (México). Universitas Psychologica, 11(2), 523-534.

Leonidas, C., Crepaldi, M. A., \& Santos, M. A. (2013). Bulimia nervosa: Uma articulação entre aspectos emocionais e rede de apoio social. Psicologia: Teoria e Prática, 15(2), 62-75.

Lettiere, A., \& Nakano, A. M. S. (2011). Violência doméstica: As possibilidades e os limites de enfrentamento. Revista Latino-Americana de Enfermagem, 19(6), 1421-1428. doi:10.1590/S0104-11692011000600020

Moré, C. L. O. O. (2014). A escuta e a rede de apoio à família em situação de violência. In L. F. Costa, M. A. Penso, \& M. I. G. Conceição (Orgs.), Abordagem à família no contexto do conselho tutelar (pp. 109-119). São Paulo, SP: Ágora.

Moré, C. L. O. O., \& Crepaldi, M. A. (2012). O mapa de rede social significativa como instrumento de investigação no contexto da pesquisa qualitativa. Nova Perspectiva Sistêmica, (43), 84-98.

Muhr, T. (2004). ATLAS.ti the knowledge workbench: V 5.0 quick tour for beginners. Berlin, Germany: Scientific Software Development.

Organização Mundial da Saúde. (2002). Relatório mundial sobre violência e saúde. Genebra, Suíça: OMS.

Orlandi, R. (2011). Participação da rede social significativa de mulheres que vivem e convivem com o HIV no enfrentamento $d a$ soropositividade (Unpublished doctoral dissertation). Universidade Federal de Santa Catarina, Florianópolis, SC.

Poll Cabrera, M., Alonso Poll, H., \& Mederos Ávila, M. E. (2012). Violencia contra la mujer en la comunidad. Medisan, 16(8), 1268-1274. 
Ramos, M. E., \& Oltramari, L. C. (2010). Atividade reflexiva com mulheres que sofreram violência doméstica. Psicologia: Ciência e Profissão, 30(2), 418-427. doi:10.1590/S1414-98932010000200015

Santi, L. N., Nakano, A. M. S., \& Lettiere, A. (2010). Percepção de mulheres em situação de violência sobre o suporte e apoio recebido em seu contexto social. Texto \& Contexto - Enfermagem, 19(3), 417-424. doi:10.1590/S0104-07072010000300002

Santos, A. C. W., \& Moré, C. L. O. O. (2011). Repercussão da violência na mulher e suas formas de enfrentamento. Paidéia (Ribeirão Preto), 21(49), 227-235. doi:10.1590/S0103-863X2011000200010

Secretaria de Políticas para as Mulheres. (2011). Diretrizes nacionais para o abrigamento de mulheres em situação de risco e violência. Brasília, DF: SPM/PR.

Sluzki, C. E. (1997). A rede social na prática sistêmica: Alternativas terapêuticas (C. Berliner, Trans.). São Paulo, SP: Casa do Psicólogo.

Strauss, A., \& Corbin, J. (2008). Pesquisa qualitativa: Técnicas e procedimentos para o desenvolvimento de teoria fundamentada (L. A. Rocha, Trans., 2nd ed.). Porto Alegre, RS: Artmed.

Waiselfisz, J. J. (2012). Mapa da violência 2012: Atualização: Homicídio de mulheres no Brasil. Rio de Janeiro, RJ: CEBELA/FLACSO Brasil.

Scheila Krenkel is a Ph.D. candidate in the Graduate Program in Psychology at Universidade Federal de Santa Catarina.

Carmen Leontina Ojeda Ocampo Moré is a Full Professor of the Centro de Filosofia e Ciências Humanas at Universidade Federal de Santa Catarina.

Cibele Cunha Lima da Motta is a post-doctoral fellow of the Centro de Filosofia e Ciências Humanas at Universidade Federal de Santa Catarina.

Received: Apr. 27, 2014

1st Revision: Sep. 29, 2014

2nd Revision: Nov. 23, 2014

Approved: Jan. 6, 2015

How to cite this article:

Krenkel, S., Moré, C. L. O. O., \& Motta, C. C. L. (2015). The significant social networks of women who have resided in shelters. Paidéia (Ribeirão Preto), 25(60), 125-133. doi: 10.1590/1982-43272560201515 